\title{
INTERPERSONAL RELATIONSHIPS IN SHAPING THE MANAGER'S COMPETENCIES IN AN ENTERPRISE - THEORETICAL ANALYSIS OF THE RESEARCH PROBLEM
}

\begin{abstract}
Interpersonal relationships play a fundamental role in the development of not only the people (employees) but the whole organization. The quality of these relationships affects the broadly understood development potential of employees and organizations. The aim of the study is to conduct a theoretical analysis of the role of interpersonal relations in shaping the manager's competencies in the organization. The following research hypothesis was adopted: (RH 1) interpersonal relationships and managerial competencies form the General Interpersonal Relationships of the Manager's Competence. This study is a review of the literature on the subject. The study has a theoretical and conceptual character.
\end{abstract}

Keywords: managerial competencies, interpersonal relationships, general interpersonal relations of the manager's competence.

\section{INTRODUCTION}

All managers (Leśniewski, 2016) subscribe to the view that people are the foundation of an enterprise. Efficient and effective functioning of a person in an organization depends on many factors, including interpersonal relations and competences. From the point of view of the management process execution, it is the manager who is the source of interpersonal relations that contribute to the creation of the manager's competences. Through interpersonal relations ${ }^{3}$ managers create their competences which in turn contribute to the managers' own development and the enterprise's competitive advantage on the market. The ma-

${ }^{1}$ Agnieszka Rzepka, DSc PhD, Associate Prof., Department of Economics and Economic Management, Faculty of Management, Lublin University of Technology, ul. Nadbystrzycka 38, Lublin; e-mail: a.rzepka@pollub.pl (corresponding author). ORCID: 0000-0003-4495-6066.

2 Michał Adam Leśniewski, PhD, Institute of Management, The Faculty of Law, Management and Administration, The Jan Kochanowski University (JKU) in Kielce, e-mail: michaladam.lesniewski@wp.pl. ORCID: 0000-0003-2411-8911.

${ }^{3}$ It should be remembered that interpersonal relationships can be of a negative and a positive character, which resembles the division between negative and positive competencies. This study only refers to the positive interpersonal relationships and competencies. It is theoretically supposed that each enterprise and the people employed in it focus primarily on positive activities as part of positive psychology. 
nager - subordinates as well as the subordinates - manager types of relationships are very important. Interpersonal relationships and managerial competences should form an integrated system for shaping the development of employees of the entire organization. A manager with positive interpersonal relationships can build his own set of competences, thanks to which he will influence subordinates and motivate them to strengthen and improve the organization.

The research problem discussed in this study assumes that the value of the manager's work is the value of his subordinates' work, i.e. the relationships that the manager maintains with other people, which builds his competences. In each organization one can observe a situation where the manager chooses to work with those subordinates (co-workers) who will build the value of the given manager and, as a consequence, the value of the organization.

The aim of the study is to conduct a theoretical analysis of the role of interpersonal relations in shaping the manager's competencies in the organization. The following research hypothesis was adopted: (RH 1) interpersonal relationships and managerial competencies form the General Interpersonal Relationships of the Manager's Competence. This study is a review of the literature on the subject. The study has a theoretical and conceptual character.

\section{THE MANAGER AS A DECISION MAKER}

The significance of having a manager in the organization is irrefutable from the point of view of not only the implementation of the management process but also the shaping of its development. A manager (supervisor) is a person whose most important task is to carry out the management process (Banaszak, 2005). The manager is a representative of the management team, therefore, should be characterized by a sense of responsibility, anticipation and strategic thinking. Implementation of the management process is improved by the manager through positive relations with subordinates - whenever the so-called smooth management takes place, it is easier to achieve the set goals of the enterprise (of the people working in it).

In practice, managers in organizations differ in their position (place in the organisation's hierarchy) and specialization (field of activity). Taking into account the management level, three groups of managers can be distinguished, i.e. (Banaszak, 2005):

1. Top management - a narrow group of managers who most often hold the following positions: president (CEO), general manager and vice president. Their basic tasks include defining strategic and operational goals in relation to the organization they manage. Their most developed skill ought to be conceptual skills, that is, creating new ideas, solutions, etc.

2. Middle, semi-level management - responsible for the implementation of the plans developed within the enterprise and for work coordination and control through levels subordinate to them. An example of a middle-level manager is the manager of a given department of the organization. Their most developed skill ought to be their social skills, that is, being able to exist in and cooperate with a group of employees.

3. First-line, lower management). employees coordinating and supervising work. Line managers include a brigadier or shift manager. Their most developed skills are technical skills. 
Managers can play different roles in organizations regardless of their rank or their specialization. The classical model of managerial roles was proposed by Mintzberg as a result of his analyzing the actual work habits and time management of chief executive officers. Mintzberg identified ten roles common to the work of all managers. They are included in three basic categories:

1. interpersonal roles which include the figurehead role, liaison role, the leader role (these role predispose to make relationships),

2. informational roles which include the monitor role, disseminator role, spokesperson role (these role are concerned with the information aspects),

3. decisional roles: which include the entrepreneur role, disturbance handler role, resource allocator role (these roles are concerned with the manager's process of decision making).

In order to fulfill specific management activities effectively and achieve goals, a manager must possess certain skills to maintain high efficiency. According to Katz, there are three types of skills that are essential for a successful management process (Listwan, 1997):

1. Conceptual skills - the knowledge and ability for abstract thinking and formulating ideas (concepts) including coordination, integration of interests and company activities; these skills allow the manager to see the organization as a total entity, therefore it helps the manager to effectively analyze, predict, diagnose and find creative solutions to possible problems and hurdles,

2. Human or interpersonal management skills which present the managers' ability to interact and work effectively with people, communicate with groups of employees as well as individuals; these skills enable the manager to maintain good relationships, understand and create motivation for his employees,

3. technical skills they concern the operational requirements of a given department or the entire organization and involve their ability to use the tools, methods and techniques of the specific discipline

The analytical and diagnostic skills are also found in the literature on the subject. They enable the manager to react appropriately in a given situation, eg in the context of diagnosing and analyzing problems occurring in an enterprise by examining their symptoms and preparing appropriate solutions.

\section{INTERPERSONAL RELATIONS IN BUILDING MANAGERIAL COMPETENCE}

Human capital represents the primary asset and a starting point in the development of an enterprise. As a primary asset, people are the source of interpersonal relationships in an enterprise. Interpersonal relationships are one of the crucial factors in building competence (Rzepka, 2017), not only for subordinates (subordinates' competences), but also for managers (managerial competencies). In a detailed view, interpersonal relationships in an organization are built on the basis of the work carried out, i.e. one can speak about the humanization of these relationships (humanization of work). Mikuła proposes that the essence of the humanization of work should be understood as an understanding of the factors that affect people negatively or limit human rationality, and the methods that allow a person to gain self-realization and satisfaction through his work (Mikuła, 2009). Humanization of relationships in the workplace takes place wherever efforts to empower a working person are undertaken, which influences the development of talents and skills, results in work satisfaction 
and contributes to the development of competences. The essence of humanization is expressed through a positive attitude towards staff, the appreciation of their unique individual contribution to the functioning of the organization, and the creation of work conditions that allow them to express themselves through their work. In the manager-subordinate relationship, this would apply to the attitude of managers to the employees subordinate to them. Managers come to the fore when it comes to the implementation of the management process. If they are in good relations with their subordinates, they constitute a team of development prospects in the conditions of a competitive market. The manager (supervisor) and the subordinate (executive worker) are the links of strategic management and operational management. What constitutes the manager's value in the management process are competences. The value of competence was acknowledged by D. McClelland who was the first to use the definition of competence at the turn of the sixties and seventies of the twentieth century. At the time, he proposed an research to find the features he described as the competences of an individual, and not the study of personality traits as had been suggested before. Nowadays, several meanings can be attributed to competence. Initially, they were understood as a formal right to deal with specific matters and make decisions to a certain extent, while representing the given organization. However, the individual's predispositions for efficient and effective operation were associated with qualifications (Oleksyn, 2006). Already in the eighties of the twentieth century, competences began to be treated much more broadly, namely as the scope of duties, rights and responsibilities of the employee assigned to a specific job. A fundamental breakthrough in the context of the discussed topic was the formulation of the definition of competence by R. Boyatzis. He described it as a potential occurring in a human being that leads to behavior, which consequently contributes to satisfying the requirements specified for a given job position within the parameters of the business environment, which in turn results in the desired results (Armstrong, 2007). Ultimately, however, an extended definition of competences was adopted, which at the same time began to replace the term "qualifications". Competences can also be applied to knowledge, because in the practice of managing organizations a competent person is identified with a man of knowledge. This means that a competent person has specific knowledge about a given problem and is able to solve the problem with various methods.

In the literature on the subject, two trends can be identified concerning the definition of competences. The first trend concerns competences that are related to the individual's potential. They are often referred to in the literature of the subject as personal competences, which are broadly understood as the scope of skills and knowledge as well as responsibility and authority to act. They are identified with a set of behaviors that certain people perform and master better than others. The result of this situation is that in certain circumstances these people act and perform more efficiently (Sidor-Rządkowska, 2006). Abilities, interests and personality traits are not without significance in terms of personal competences these are exemplary parameters that differentiate people from one another (Levy-Leboyer, 1997). The second trend is a group of terms that refer to competencies correlated with the job or occupational position. In the literature, they are referred to as employee competencies. They should be understood as the scope of potential in the area of work performed by the individual, which consists of a set of characteristics such as motivation, skills, personality traits, self-esteem related to the functioning of the team as well as the knowledge that the individual has acquired and used (Whiddett, Hollyforde, 2003). Employee competencies are the dispositions of the individual in terms of knowledge, attitudes, and skills that allow them to perform their professional tasks at the appropriate level (Leśniewski, 2015). 
The key difference between the above-mentioned trends refers to the treatment of competences in an independent, absolute context (first trend) and relativization of competences to the organization's goals (the second one) and the resulting tasks to be carried out. Accordingly, when talking about competences in the work process, it is necessary to take into account the demands made by it. At the same time, the need to achieve specific goals and objectives relating to the organization in the overall dimension should be taken into account.

Competence is understood as the ability to use and apply knowledge in professional aspects. It is a cluster of an individual's abilities to work effectively, to achieve goals and to comply with the required performance standards.

Regardless of the differences in the aforementioned two trends, the vast majority of authors struggle with the need to define competence components. They ultimately make up the general potential that characterizes each individual that is observable in his work and allows him to perform his work at the right level (Armstrong, 2007). The potential of a human being can be identified with competencies that enable people to achieve the goals/goals and the organization in which they work - this can be understood by the following motto: the quality of the employees shows the quality of the enterprise. These words illustrate not only competence but the functioning of an employee in the enterprise. Conducting competence analysis is part of the soft competitiveness of enterprises and soft management (Leśniewski, 2015).

An appropriate point of reference for specifying specialized competence components is the following typology (Sajkiewicz, 2002):

1. talents, or the condition of the individual's capital that reflect his development potential. These include, among others, acquiring new and improving the existing competences,.

2. skills - knowledge of specific issues and proficiency in related tasks. These include communication, conceptual, technical, organizational and business skills, staff's attitudes towards clients, their attitude to work, as well as leadership skills and managing the staff,

3. knowledge - insight into and understanding of theories, procedures, facts concerning the specificity of a given position, occupation, etc.

4. physical condition - physical requirements for a specific position. These include, among other things, good physical condition, psycho-physical ability or sharpness of the senses,

5. work style - competences that relate to the way the tasks entrusted to the employee are performed. Work styles are divided into the employee and managerial ones,

6. personality - a collection of individual characteristics of a human being,

7. values and principles - beliefs of the individual influencing determinants of his behavior at the workplace,

8. interests - individual preferences of employees that influence their chosen educational and professional career path.

Considering the currently existing market reality, the development of competences is a process forced on the present day enterprises. It is related to the synchronization of internal policy, strategic and operational goals, directions of expansion, taking into account external and internal conditions. Undoubtedly, the organization shaping and verifying its mission and strategy is obliged to recognize possible problems in a very dynamically changing environment and to adapt the competences - among its other assets - of persons employed to the existing conditions. 
In order for competences to bring benefits to people and organizations, they must be associated with various aspects of the organization's development. Competencies are associated not only with finance, marketing, logistics or technology, but also with competitiveness, where, thanks to employees' competencies, one can create such a potential that will allow one to achieve a competitive advantage. The link between competences and competitiveness is reflected in the soft competitiveness model by Michał Adam Leśniewski (2015).

The development of competences is associated, among others, with the methodology of designing competence models. The portfolio of competencies should be understood as a set of competences selected in such a way that their use at work could maximize the probability of effective, effective and appropriate performance of tasks by employees, and fulfill their functions in the organization and their position. Depending on the organization, competencies should be shaped in different ways so that they consider the specificity of the work. For example, a scientist should demonstrate competence in creating concepts and ideas, and should publish his work results in various publications (in monographs, articles etc.). However, a person working in the company as a manager should demonstrate competence in assessment, should help subordinates and should be able to cooperate within the structures of the enterprise, etc. Depending on the organization, competences are shaped in a way that they find their recognition in the specifics of a given economic entity. Figure 1 presents the general interpersonal relationships of the manager's competences.

Figure 1. General Interpersonal Relationships of the Manager's Competencies

Ogólne Relacje Międzyludzkie Kompetencji Menedżera - a conceptual model

\begin{tabular}{|c|c|c|}
\hline Manager's knowledge & Manager's experience & $\begin{array}{c}\text { Manager's Knowledge of the } \\
\text { organization's resources }\end{array}$ \\
\hline $\begin{array}{c}\text { Manager-subordinate } \\
\text { relationship }\end{array}$ & $\begin{array}{c}\text { Relationships with other } \\
\text { managers }\end{array}$ & $\begin{array}{c}\text { External relations of the mana- } \\
\text { ger with other organizations }\end{array}$ \\
\hline $\begin{array}{c}\text { Manager's intellectual } \\
\text { abilities }\end{array}$ & $\begin{array}{c}\text { Manager's behaviorality } \\
\text { Manager's abilities }\end{array}$ \\
\hline Manager's perception & Manager's assertiveness & Manager - coach \\
\hline
\end{tabular}

Legend: Vertical double-sided outward arrows mean that all the factors of the model must be synergic - complementary to each other and constitute a compact whole.

Source: own study.

The model presented in Figure 1 looks at the interpersonal relationships and the manager's competencies in an integrated manner. The authors of the model distinguish between two categories of interpersonal relationships - general interpersonal relationships and relationships with other people. General interpersonal relationships are interactions maintained by employees within the organization and outside of it. They fall into the broadlyunderstood category of relationships. On the other hand, the category of relationships with other people includes detailed forms of relationships such as the manager's relationship with 
subordinates, relations with other managers, the manager's external relations with other organizations. Yet another approach that has been adopted in Figure 1 is the joint approach to interpersonal relationships and managerial competencies in the form of general interpersonal relationships of the manager's competence. Interpersonal relations that shape managerial skills are the starting point of the presented model. The general interpersonal relations of the manager's competences are developed by the general factors that were presented in the model in Figure 1. The order of the factors is irrelevant. There should be interaction between the factors to achieve the effectiveness and efficiency of the presented model. The factors of the model should be considered in terms of quality, because the quality of these factors determines the success in developing this model. No organization is about the number of relationships, but about their quality because they result from quality. The quality of model factors is visible, for example, in the quality of knowledge, the quality of experience, the quality of relationships or the quality of the organization's resources. The word "quality" can be added to every factor of the model: the essence of the word is hidden in the structure of the given factor The authors of the model assume that the quality of each factor is the starting point for the development of the organization. Each model can be interpreted, which means that the success or failure of the implementation of this model depends on the quality of the manager. In the opinion of the authors, the implementation of this model requires the implementation of a qualitative approach because the employee's quality is the starting point for any changes.

\section{SUMMARY}

Interpersonal relationships are the basis for any human-initiated action in and outside the enterprise. The development of the organization can be seen through relationships existing between people. These relationships can create positive bonds - and these have been the subject of this study - as well as negative ones. The manager must create positive interpersonal relationships, not only with other managers but also with subordinates. Positive interpersonal relationships between the manager and the subordinates are at the root of the enterprise's development. The analysis of interpersonal relationships supports the view that these relationships tend to change their character in a dynamic way. Although relationships can be built quickly, they can be destroyed just as instantly by the wrong approach to the employee. As previously stated, interpersonal relationships are the basis of various activities of the organization and contribute to shaping competences. In this study, interpersonal relations are focused on the manager's competences. A wise managers will always listen to employees and will draw conclusions that will affect his decisions. Literature review along with logical thinking confirms the adopted research hypothesis, which takes the form of the following thesis: (T1) interpersonal relationships and managerial competencies form the Interpersonal Relationships of the Manager's Competencies. The research problem formulated in this paper may serve as the basis for further theoretical or empirical research (theoretical-empirical) and strengthen the process of quality management of human resources in the enterprise. 


\section{REFERENCES}

Armstrong, M. (2007). Zarządzanie zasobami ludzkimi. Kraków: Wolters Kluwer business.

Banaszak, S. (2005). Menedżerowie w strukturze społecznej. Poznań: Wyższa Szkoła Komunikacji i Zarządzania w Poznaniu.

Filipowicz, G. (2004). Zarzqdzanie kompetencjami zawodowymi. Warszawa: PWE.

Levy-Leboyer, C. (1997). Kierowanie kompetencjami. Bilanse doświadczeń zawodowych. Poltext, Kraków 1997.

Leśniewski, M.A. (2015). Konkurencyjność miękka przedsiębiorstw. Difin, Warszawa 2015.

- (2016). The role of a manager in shaping behavioural cultural competitive advantage of the enterprises. "Jagiellonian Journal of Management", t. 2. DOI: 10.4467/2450114XJJM. 16.009.5559

- (2017). Man as creator of behavioural competitiveness of enterprises - conceptual model. “Jagiellonian Journal of Management”, t. 3. DOI: 10.4467/2450114XJJM.17.010.9561.

Listwan, T. (1997). Kształtowanie kadry menedżerskiej firmy. Kadry, Wrocław.

Mikuła, B. (2009). Humanizacja w zarzadzaniu. „Zeszyty Naukowe Uniwersytetu Ekonomicznego w Krakowie", nr 801.

Oleksyn, T. (2006). Zarządzanie kompetencjami. Teoria i praktyka. Kraków: Oficyna Ekonomiczna.

Rzepka, A. (2017). Inter-organizational relations as a one of sources of competitive advantage of contemporary enterprises in the era of globalization. „Procedia Engineering”, No. 174.

(2018). Relacje międzyorganizacyjne i kapitat intelektualny jako czynniki rozwoju mikro $i$ matych przedsiębiorstw. Studium na przykładzie wybranych przedsiębiorstw polskich i gruzińskich. Warszawa: Difin.

Sajkiewicz, A. (2002). Jakość zasobów pracy. Kultura, kompetencje, konkurencyjność. Warszawa: Poltext.

Sidor-Rządkowska, M. (2002). Ksztattowanie nowoczesnych ocen pracowniczych. Kraków: Oficyna Ekonomiczna.

Whiddett, S., Hollyfirde, S. (2003). Modele kompetencyjne w zarządzaniu zasobami ludzkimi. Kraków: Oficyna Ekonomiczna.

DOI: 10.7862/rz.2019.mmr.13

The text was submitted to the editorial office: May 2019.

The text was accepted for publication: June 2019. 